\title{
Marker Assisted Gene Pyramiding of Leaf Rust Resistance Genes Lr24 and Lr28 in the Background of Wheat Variety DWR 162 (Triticum aestivum L.)
}

\author{
G. Anil Kumar ${ }^{1 *}$, R.R. Hanchinal ${ }^{2}$, Shrinivas Desai ${ }^{1}$ and Suma Biradar ${ }^{3}$ \\ ${ }^{1}$ Department of Genetics and Plant Breeding, University of Agricultural Sciences, \\ Dharwad - 580005, Karnataka, India \\ ${ }^{2}$ Chairperson, PPV and FR Authority, Ministry of Agriculture, \\ Government of India, New Delhi, India \\ ${ }^{3}$ MARS, University of Agricultural Sciences, Dharwad - 580005, Karnataka, India, India \\ *Corresponding author
}

A B S T R A C T

Ke y w o r d s
Triticum aestivum
L., Pyramiding,
Leaf rust,
Resistance genes,
Molecular markers.
Article Info
Accepted:
21 July 2017
Available Online:
10 September 2017

Keywords

Triticum aestivum

L., Pyramiding,

Molecular

Accepted:

Available Online:

\section{Introduction}

Rusts are the most devastating fungal diseases posing a threat towards realizing the potential yield in wheat, worldwide. Wheat is attacked by three rust species: leaf rust (Puccinia triticina Eriks.), stem rust ( $P$. graminis f. sp. graminis Eriks. \& E. Henn) and stripe (yellow) rust ( $P$. striiformis Westend.). Leaf rust caused by Puccinia triticina is the most common and widely distributed of the three wheat rusts.

Chemical control of rust pathogens is inefficient, expensive and cannot be adopted by small and marginal farmers. Therefore, an effective, economical, and ecologically safe method to control leaf rust epidemics is the breeding and cultivation of resistant wheat varieties.

Improving resistance to rust fungi is one of the major tasks facing wheat breeders all over the world. Although conventional gene transfer offers useful means of introgressing or pyramiding more than one well characterized resistance gene into susceptible genetic background, however, when no 
distinguishing virulence is available for pyramiding two effective major genes, conventional technique is not useful for precisely pyramiding these genes in single genetic background. The use of molecular markers facilitates the incorporation of the major leaf rust resistance genes ( $L r$ genes) responsible for resistance into new varieties and the pyramiding of these genes.

Breeding programs have successfully implemented molecular markers to assist in the development of cultivars with stem, leaf and stripe rust resistance genes. Rust pathotypes however overcome resistance genes through mutation and genetic recombination (Dadkhodaie et al., 2011). It is thus necessary to constantly improve the genetic resistance of commercially grown wheat cultivars and to explore novel sources of genetic resistance.

Several rust resistance genes are available in the common wheat background originating from Triticum and its wild relatives like, Agropyron, Aegilops and Secale. Wild relatives of wheat serve as an abundant genetic resource for improving the genetic variation in cultivated wheat (Dadkhodaie et al., 2011). Plant breeders have access to the primary (Triticum spp.), secondary (Aegilops spp.) and tertiary (Tritiaceae spp.) gene pools of wheat, primarily constituted of wild wheat species and related grasses. A greatest hope for improving the rust resistance in wheat lies in exploiting some of these valuable species possessing useful genes. A large number of $\mathrm{Lr}$ genes providing resistance to leaf rust and stripe rust pathogens world over have been documented (McIntosh et al., 2007). Among these, the alien leaf rust resistance genes, Lr24 derived from Agropyran elongatum and Lr28 originating from Aegilops speltoides provide effective resistance against all the Indian leaf rust pathotypes (Tomar and Menon, 2001). The alien segment carrying Lr24/ Sr24 does not impose any deleterious effect on yield as several cultivars carrying Lr24 have been released for cultivation in India (Singh et al., 2007). Although, Lr28 has not yet been commercially deployed on large scale, but a cultivar MACS6145 (=HW2034) carrying this gene has been released for North Eastern zone in India (Rao et al., 2007).

Deployment of single resistance gene will not be effective because large-scale and long-term cultivation of such resistant varieties may result in significant shifts in the virulence pattern of the pathogen population leading to breakdown of resistance. Pyramiding multiple resistance genes in a single variety is an attractive strategy to prevent or delay the breakdown of resistance. The duration and efficiency of the rust resistance genes utilized within a wheat cultivar can be improved by pyramiding multiple resistance genes in the same cultivar (Simons et al., 2011).

\section{Materials and Methods}

The bread wheat genotype DWR 162, which is susceptible to leaf rust, was selected as recipient parent for pyramiding the leaf rust resistance genes, $L r 24, L r 28$. 'PBW 343' near isogenic lines with $L r 24$ and $L r 28$ developed through marker assisted backcross breeding were used as donor parent for introgression of leaf rust resistant genes. The parents DWR 162 and NIL PBW 343, BC2F1 (generated by Arati et al., 2013), BC2F2, were sown and desired selections were made at All India Coordinated Wheat Improvement Project (AICWIP), Main Agricultural Research Station (MARS), University of Agricultural Sciences, Dharwad. Normal agronomical practices were followed for raising the crop.

\section{Seedling test and field inoculations}

Three weeks old seedlings of parental lines and segregating generations were inoculated in the field with selected pathotypes of leaf rust 77-5 (121R63-1). The pure inoculum of 
rust pathotypes was obtained from the Directorate of Wheat Research, Regional Station, Flowerdale, Shimla Rust severity was recorded according to the modified Cobb's scale described and was estimated on the basis of percentage area covered with pustules (Peterson et al., 1948).

\section{PCR analysis}

DNA was isolated from young leaves by a modified CTAB method (Dellaporta et al., 1983). PCR reactions were performed in a total volume of $25 \mu \mathrm{l}$, containing $1 \times$ PCR buffer, $200 \mu \mathrm{M}$ of each dNTP, $20 \mathrm{ng}$ of each primer, $1 \mathrm{U}$ of Taq DNA polymerase (Banglore Genei Pvt. Ltd., India) and $100 \mathrm{ng}$ of genomic DNA in a PTC-200 thermal cycler (MJ Research).

Primers were synthesized from Sigma Aldrich Pvt. Ltd., Bangalore, India. The sequence of primers and the PCR conditions used for amplification presented in (Table 1). Amplified PCR products were resolved in 2\% agarose gel, stained with ethidium bromide.

\section{Results and Discussion}

The recipient parent DWR 162, donor parent NIL PBW 343, were validated for the presence/absence of $\operatorname{Lr} 24$ and Lr28 genes with the help of SCAR markers linked to leaf rust resistance genes, Lr24 and Lr28. These markers showed amplification of specific marker fragments of 719bp size with the SCAR marker SCS73719 and 607bp fragment with the SCAR marker SCS1302, both linked to $L r 24$, in the donor parent NIL PBW 343 and 570bp fragment with SCAR marker SCS421 and 320bp fragment with SSR marker Xwmc313, both linked to $L r 28$, in the donor parent NIL PBW 343 (Plate 1 to 3). There was absence of amplification of specific marker fragments of sizes 719bp with the SCAR marker S73719 and 607bp with the
SCAR marker SCS1302 linked to Lr24 and 570 bp fragment with the SCAR marker S421 and 320bp fragment with SSR marker Xwmc313 linked to $L r 28$, in the recipient parent DWR 162. This confirms the presence of resistance genes in the donor parent NIL PBW 343 and their absence in recipient parent DWR 162. Thus these markers can be effectively utilized marker assisted selection of both the leaf rust resistance genes $L r 24$ and Lr28.

Field screening of the donor parent, NIL PBW 343, and recipient parent, DWR 162 for seedling and Adult Plant Resistance (APR) with most virulent leaf rust pathotype 77-5, showed that DWR 162 is highly susceptible with a very high seedling infection score of ' $3+$ ' and adult plant reaction indicating that this variety is highly susceptible (Table 2).

$\mathrm{BC}_{2} \mathrm{~F}_{1}$ progeny generated by Arati et al. (2013) was subjected to marker assisted foreground selection using SCAR and SSR markers. Genotypes with the leaf rust resistance genes Lr24 and Lr28 using linked SCAR markers SCAR: SCS719 and SCS1302 for $L r 24$ and SCAR: SCS421 for $L r 28$ respectively were advanced to $\mathrm{BC}_{2} \mathrm{~F}_{2}$ generation.

One hundred and twenty $\mathrm{BC}_{2} \mathrm{~F}_{2}$ plants were subjected to foreground selection with markers linked to leaf rust resistance genes Lr24 and Lr28. Foreground selection of plants with SCAR markers SCS1302 linked to Lr24 and SCAR marker SCS421 linked to $L r 28$ showed 60 plants carrying both Lr24 by amplifying 607 bp size band (Plate 1) and Lr28 by amplifying 570 bp size band (Plate 2 ), leaf rust resistance genes, 20 plants with only Lr24 gene, 23 plants with only Lr28 and 11 plants showed absence of both the genes. Foreground selection with another SCAR marker SCS73719 linked to Lr24 showed the presence of the gene by amplifying 719bp 
size band in all the plants carrying Lr24 confirmed by SCS1302. The expected segregation of the SCAR markers SCS1302 and SCS421 in the ratio of 9:3:3:1 in BC2F2 generation (Table 3) was recorded indicating the goodness of fit with a calculated $\chi^{2}$ value of 2.76 (table $\chi^{2}$ value 7.82 ) as revealed from the results of $\chi 2$ test.

Since Xwmc313 is a co-dominant marker it facilitated the identification of plants as homozygous or heterozygous for leaf rust resistance gene $L r 28$. A perusal of table 4 shows that molecular marker Xwmc313 identified 23 plants as homozygous resistant and 48 plants as heterozygous resistant carrying Lr28. SCAR marker SCS1302 identified 80 plants positive for leaf rust resistance gene $\operatorname{Lr} 24$ out of 120 plants studied. Since, SCS1302 is a dominant marker, these 80 identified individuals included both homozygous and heterozygous resistant plants for Lr24. Joint segregation analysis of two markers i.e., one co-dominant marker Xwmc313 for $\operatorname{Lr} 28$ and a dominant marker SCS1302 for Lr24 was undertaken to identify plants with different genotypic constitution with respect to the two rust resistance genes. The expected and observed frequencies of different genotypic classes are shown in table 4 . Out of 23 plants identified as homozygous resistant for $L r 28,16$ were observed to carry leaf rust resistance gene Lr24 as well, either in homozygous or heterozygous condition. Remaining 7 plants, homozygous for $\operatorname{Lr} 28$ did not carry $L r 24$ gene. Out of 48 plants identified as carrying Lr28 in heterozygous state, 36 also carried leaf rust resistance gene $L r 24$ either in homozygous or heterozygous condition as against an expected frequency of 45.12 plants were observed to carry only $\operatorname{Lr} 28$ in heterozygous condition as against an expectation of 15 . Twenty three plants were observed to carry only Lr24 either in homozygous or heterozygous state. Out of 120 plants 11 did not carry either Lr24 or
Lr28 as against expected value of 7.5. The six categories of genotypic classes expected from segregation of a dominant and a co-dominant marker are shown in the table 4. A perusal of the table shows that the observed values of the six genotypic classes fits well with the expected ratio of $3: 1: 6: 2: 3: 1$ with a nonsignificant $\chi 2$ value of 5.96 .

Individual plants of $\mathrm{BC}_{2} \mathrm{~F}_{2}$ generation were studied for their performance in the presence of individual leaf rust resistant genes $L r 24$ or Lr28 and in the presence of both Lr24 and Lr28 together (Table 5). Individual plants were compared with each other for agronomic characters such as days to 50 percent flowering, number of tillers per plant, spike length, spikelets per spike, grain yield per plant, thousand grain weight and leaf rust resistance to know the effect of these genes in the background of DWR 162.

Perusal of results indicated that the plants carrying $L r 24$ gene were on par with plants which carry $\operatorname{Lr} 28$ for characters such as days to 50 percent flowering and plant height. For leaf rust resistance, plants with $L r 24$ recorded very low coefficient of infection as compared to plants with Lr28 (Table 5). The alien segment carrying Lr24 does not impose any deleterious effect on yield as several cultivars carrying Lr24 have been released for cultivation in India (Singh et al., 2007).

Plants carrying $L r 28$ gene were superior for all agronomic characters such as number of tillers per plant, spike length, spikelets per spike, grain yield per plant and thousand grain weight. This could be attributed to the presence of $\operatorname{Lr} 28$ gene which contributes for superior agronomic traits along with rust resistance. The similar reports of increased grain yield, 1000-grain weight and number of effective tillers per plant due to the presence of $L r 28$ gene has been reported by Kumar and Raghavaiah (2004). For leaf rust, high resistance has been recorded in plants with 
Lr28, which controls one of the important resistances in the Indian subcontinent against the most prevalent Puccinia triticina pathotype 77-5. $\operatorname{Lr} 28$ gene has been reported to contribute for superior agronomic traits along with rust resistance (Kumar and Raghavaiah, 2004) without any deleterious effects.

Table.1 Molecular markers for foreground selection of rust resistance genes used in the study

\begin{tabular}{|c|l|l|c|c|}
\hline $\begin{array}{c}\text { Genes } \\
\text { tagged }\end{array}$ & $\begin{array}{c}\text { Molecular } \\
\text { markers }\end{array}$ & \multicolumn{1}{|c|}{ Primer sequence 5'---3' } & $\begin{array}{c}\text { Amplification } \\
\text { product } \\
\text { size(bp) }\end{array}$ & References \\
\hline Lr24 & SCAR:SCS719 & $\begin{array}{l}\text { F: TCG TCC AGA TCA GAA TGT G } \\
\text { R: CTC GTC GAT TAG CAG TGA G }\end{array}$ & 719 & $\begin{array}{c}\text { Prabhu } \text { et al., } \\
\text { (2004). }\end{array}$ \\
\hline Lr24 & SCAR:SCS1302 & $\begin{array}{l}\text { F: CGC AGG TTC CAA TAC TTT TC } \\
\text { R: CGC AGG TTC TAC CTA ATG CAA }\end{array}$ & 607 & $\begin{array}{c}\text { Gupta } \text { et al., } \\
(2006) .\end{array}$ \\
\hline Lr28 & SCAR:SCS421 & $\begin{array}{l}\text { F: ACA AGG TAA GTC TCC AAC CA } \\
\text { R: AGT CGA CCG AGA TTT TAA CC }\end{array}$ & 570 & $\begin{array}{c}\text { Cherukuri } \text { et } \\
\text { al., }(2005) .\end{array}$ \\
\hline Lr28 & SSR:Xwmc313 & $\begin{array}{l}\text { F: GCAGTCTAATTATCTGCTGGCG } \\
\text { R: GGGTCCTTGTCTACTATGTCT }\end{array}$ & 320 & $\begin{array}{c}\text { Annapurnalily } \\
\text { et al., }(2011)\end{array}$ \\
\hline
\end{tabular}

Table.2 Screening of parental lines under artificial inoculated conditions at Seedling and adult stage

\begin{tabular}{|c|c|c|}
\hline Parental lines & \multicolumn{2}{|c|}{ Reaction to leaf rust } \\
\hline & Seedling score & APR \\
\hline DWR 162 & $3+$ & $80 \mathrm{~S}$ \\
\hline PBW 343 & $; 0$ & $; 0$ \\
\hline
\end{tabular}

APR $=$ Adult plant response; $S=$ Susceptible (Large uredia with or without necrosis or chlorosis); $0=$ No infection

Table.3 Observed and expected number of plants with $\operatorname{Lr} 24, \operatorname{Lr} 28$ and $\operatorname{Lr} 24$ and $\operatorname{Lr} 28$ in $\mathrm{BC}_{2} \mathrm{~F}_{2}$ generation of DWR 162 X NIL PBW 343 based on joint segregation of linked SCAR markers

SCS1302 ( $\operatorname{r24}$ ) and SCS421(Lr28)

\begin{tabular}{|c|l|c|c|c|c|}
\hline \multirow{2}{*}{$\begin{array}{c}\text { Sl. } \\
\text { No. }\end{array}$} & \multirow{2}{*}{ Genotypic class } & \multicolumn{2}{|c|}{ Number of plants } & \multirow{2}{*}{ Cal $\boldsymbol{\chi} \mathbf{2}$} & \multirow{2}{*}{ Tab $\boldsymbol{\chi} \mathbf{2}$} \\
\cline { 3 - 4 } & & Observed & Expected & & \\
\hline 1 & A_B_(9) & 60 & 67.5 & 0.84 & \\
\hline 2 & A_bb (3) & 20 & 22.5 & 0.28 & \\
\hline 3 & aaB_(3) & 23 & 22.5 & 0.01 & \\
\hline 4 & aabb (1) & 11 & 7.5 & 1.64 & \\
\hline & Total & $\mathbf{1 2 0}$ & $\mathbf{1 1 4}$ & 2.76 & 7.82 \\
\hline
\end{tabular}

$\mathrm{A}=\operatorname{Lr} 24, \mathrm{~B}=\operatorname{Lr} 28$ 
Table.4 Joint segregation of linked SSR marker Xwmc313 (Lr28) and SCAR marker SCS1302 (Lr24) in $\mathrm{BC}_{2} \mathrm{~F}_{2}$ generation of DWR 162 X NIL PBW 343

\begin{tabular}{|c|c|c|c|c|c|}
\hline \multirow{2}{*}{$\begin{array}{l}\text { Genotypic } \\
\text { Frequency }\end{array}$} & \multirow{2}{*}{ Expected } & \multicolumn{2}{|c|}{ No of Plants } & \multirow{2}{*}{ Cal $\chi^{2}$} & \multirow{2}{*}{$\operatorname{Tab} \chi^{2}$} \\
\hline & & $\mathbf{E}$ & $\mathbf{O}$ & & \\
\hline AAB- & $3 / 16$ & 22.5 & 16 & 1.88 & \\
\hline $\mathrm{AAbb}$ & $1 / 16$ & 7.5 & 7 & 0.03 & \\
\hline $\mathrm{AaB}-$ & $6 / 16$ & 45 & 36 & 1.80 & \\
\hline Aabb & $2 / 16$ & 15 & 12 & 0.60 & \\
\hline aaB- & $3 / 16$ & 22.5 & 23 & 0.01 & \\
\hline aabb & $1 / 16$ & 7.5 & 11 & 1.63 & \\
\hline $\begin{array}{l}\text { Genotypic ratio } \\
\mathrm{A}=L r 28, \mathrm{~B}=L r\end{array}$ & $3: 1$ & 120 & 105 & 5.96 & 11.07 \\
\hline
\end{tabular}

Table.5 Performance of individual plants of $\mathrm{BC}_{2} \mathrm{~F}_{2}$ in different gene combinations

\begin{tabular}{|c|c|c|c|c|c|c|}
\hline \multirow[t]{2}{*}{ Character } & Lr24 & $\operatorname{Lr} 28$ & $\begin{array}{l}L r 24 \text { and } \\
L r 28\end{array}$ & $\begin{array}{c}\text { Without } \\
\text { Lr24 or } \\
\text { Lr } 28 \\
\end{array}$ & DWR 162 & $\begin{array}{l}\text { NIL PBW } \\
\quad 343\end{array}$ \\
\hline & $\begin{array}{c}\text { Mean } \pm \\
\text { SE }\end{array}$ & $\begin{array}{c}\text { Mean } \pm \\
\text { SE }\end{array}$ & $\begin{array}{c}\text { Mean } \pm \\
\text { SE }\end{array}$ & $\begin{array}{c}\text { Mean } \pm \\
\text { SE }\end{array}$ & Mean $\pm \mathrm{SE}$ & $\begin{array}{c}\text { Mean } \pm \\
\text { SE }\end{array}$ \\
\hline $\begin{array}{l}\text { Days to } 50 \text { per cent } \\
\text { flowering }\end{array}$ & $\begin{array}{c}72.68 \pm \\
4.46\end{array}$ & $\begin{array}{c}71.67 \pm \\
2.40\end{array}$ & $\begin{array}{l}70.70 \pm \\
2.89\end{array}$ & $\begin{array}{l}71.05 \pm \\
0.55\end{array}$ & $\begin{array}{l}64.50 \pm \\
2.12\end{array}$ & $83.8 \pm 1.6$ \\
\hline Plant height $(\mathrm{cm})$ & $\begin{array}{c}76.67 \pm \\
3.67 \\
\end{array}$ & $\begin{array}{c}74.86 \pm \\
4.58 \\
\end{array}$ & $\begin{array}{c}88.25 \pm \\
8.56\end{array}$ & $\begin{array}{c}69.90 \pm \\
0.60 \\
\end{array}$ & $94.5 \pm 2.29$ & $\begin{array}{c}86.4 \pm \\
3.37 \\
\end{array}$ \\
\hline Tillers per plant & $\begin{array}{c}18.67 \pm \\
2.68\end{array}$ & $\begin{array}{c}20.43 \pm \\
4.28\end{array}$ & $\begin{array}{c}20.00 \pm \\
5.14\end{array}$ & $\begin{array}{l}11.93 \pm \\
2.67\end{array}$ & $\begin{array}{l}19.50 \pm \\
0.96\end{array}$ & $\begin{array}{c}11.7 \pm \\
0.83\end{array}$ \\
\hline Spike length $(\mathrm{cm})$ & $\begin{array}{c}9.03 \pm \\
0.44\end{array}$ & $\begin{array}{c}11.04 \pm \\
0.81\end{array}$ & $\begin{array}{c}11.75 \pm \\
0.23\end{array}$ & $\begin{array}{c}9.11 \pm \\
0.07\end{array}$ & $\begin{array}{c}12.60 \pm \\
0.50\end{array}$ & $\begin{array}{c}10.4 \pm \\
1.02 \\
\end{array}$ \\
\hline $\begin{array}{l}\text { Number of spikelets per } \\
\text { spike }\end{array}$ & $\begin{array}{c}17.53 \pm \\
0.58\end{array}$ & $\begin{array}{c}19.23 \pm \\
0.88\end{array}$ & $\begin{array}{c}22.40 \pm \\
0.60\end{array}$ & $\begin{array}{c}16.44 \pm \\
0.43\end{array}$ & $\begin{array}{c}21.90 \pm \\
0.36\end{array}$ & $\begin{array}{c}17.9 \pm \\
0.22 \\
\end{array}$ \\
\hline Grain yield per plant (g) & $\begin{array}{c}16.90 \pm \\
2.67\end{array}$ & $\begin{array}{c}21.32 \pm \\
2.15\end{array}$ & $\begin{array}{c}23.55 \pm \\
1.67\end{array}$ & $\begin{array}{c}12.26 \pm \\
0.72\end{array}$ & $\begin{array}{l}20.21 \pm \\
2.06\end{array}$ & $\begin{array}{c}16.3 \pm \\
1.23\end{array}$ \\
\hline $\begin{array}{l}\text { Thousand grain weight } \\
\text { (g) }\end{array}$ & $\begin{array}{l}36.55 \pm \\
2.04\end{array}$ & $\begin{array}{l}39.87 \pm \\
2.66\end{array}$ & $\begin{array}{c}42.17 \pm \\
1.96\end{array}$ & $\begin{array}{c}34.04 \pm \\
2.78\end{array}$ & $\begin{array}{c}38.02 \pm \\
1.62\end{array}$ & $\begin{array}{c}41.2 \pm \\
1.62\end{array}$ \\
\hline $\begin{array}{l}\text { Average coefficient of } \\
\text { infection of leaf rust }\end{array}$ & $\begin{array}{c}0.12 \pm \\
0.10\end{array}$ & $\begin{array}{c}4.55 \pm \\
3.73\end{array}$ & $\begin{array}{c}0.07 \pm \\
0.23\end{array}$ & $\begin{array}{c}65.00 \pm \\
1.52\end{array}$ & $31.5 \pm 1.58$ & $\begin{array}{c}5.33 \pm \\
1.32\end{array}$ \\
\hline
\end{tabular}




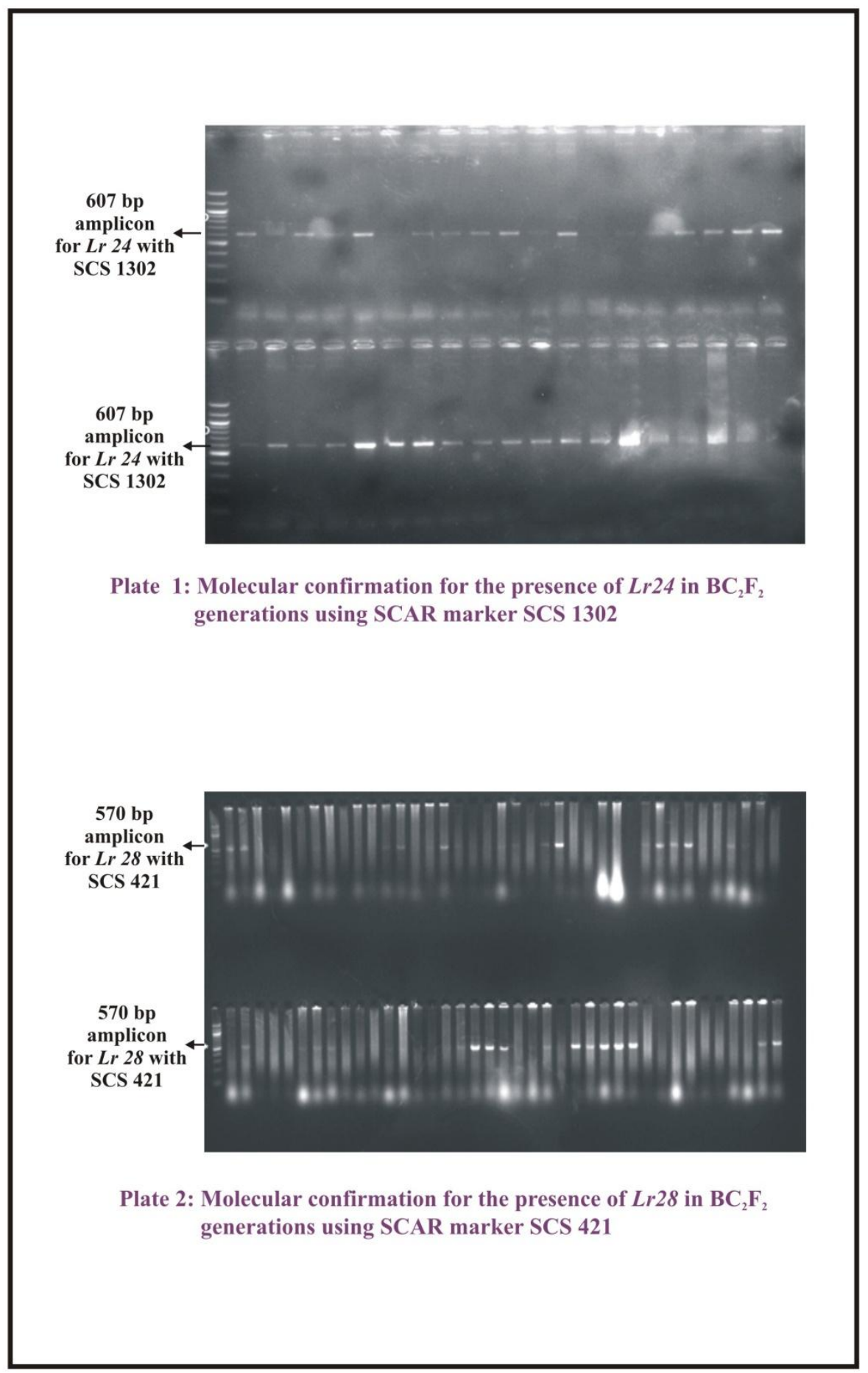




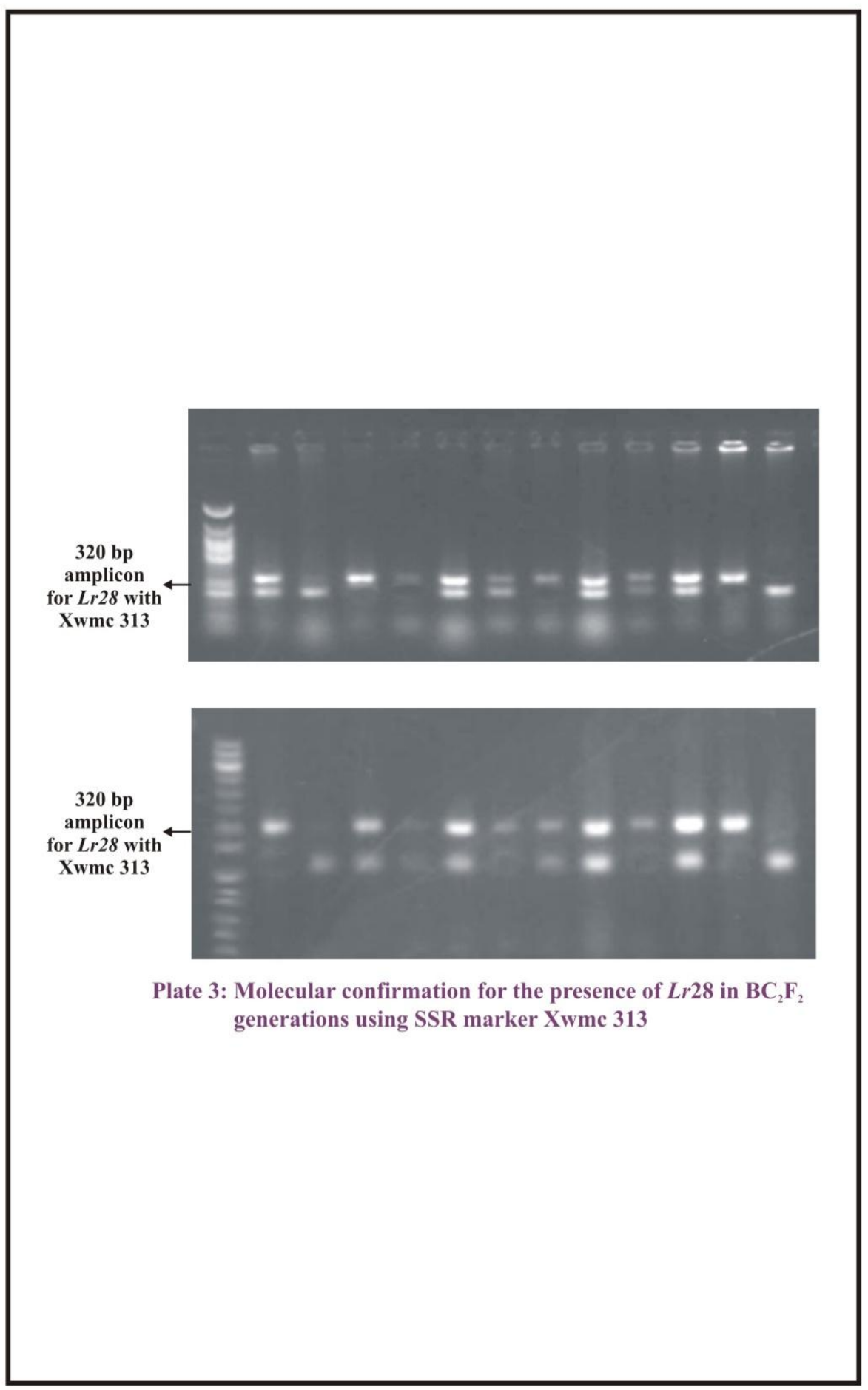


Plants with both leaf rust resistance genes Lr24 and $L r 28$ were superior in performance for all the characters along with rust resistance (with zero coefficient of infection for leaf rust) as compared to plants with individual leaf rust resistance genes, $L r 24$ or Lr28. Similar results of 'PBW 343' lines pyramided with $L r 24$ and $L r 28$ showing broad spectrum rust resistance with newly introduced leaf rust resistance genes has been reported by Chhuneja et al., (2011). This kind of interaction where the combination of genes give higher level of resistance than when present separately have been reported earlier by several authors (Kolmer et al., 1991; Kloppers and Pretorius 1997; Dyck and Samborski 1982) and often forms the basis of durable resistance.

On the contrary, plants which do not carry both $L r 24$ and $L r 28$ genes yielded less grain yield due to high susceptibility to leaf rust (Table 5).

Observations recorded on individual plants of $\mathrm{BC}_{2} \mathrm{~F}_{2}$ for morphological characters to study the phenotypic similarity of $\mathrm{BC}_{2} \mathrm{~F}_{2}$ with DWR 162 suggested good resemblance of $\mathrm{BC}_{2} \mathrm{~F}_{2}$ population with DWR 162 (Table 5).

High phenotypic association of $\mathrm{BC}_{2} \mathrm{~F}_{2}$ with DWR 162 for most of the agronomic characters like days to 50 percent flowering, number of tillers per plant, spike length, spikelets per spike and grain yield per plant suggested that, more number of backcrosses is a worthwhile exercise for higher recovery of all the desirable traits of recurrent parent(s). High phenotypic association of $\mathrm{BC}_{2} \mathrm{~F}_{2}$ plants with the recurrent parent HD 2877, indicating good recovery of all the desirable traits has been reported by Revathi et al., (2010).

For number of tillers per plant, number of spikelets per spike, thousand grain weight and grain yield per plant, $\mathrm{BC}_{2} \mathrm{~F}_{2}$ population was superior to DWR 162. This could be attributed to the desirable gene combination of both DWR 162 and NIL PBW 343 and the leaf rust resistance genes $\operatorname{Lr} 24$ and $L r 28$. Superior performance of backcross lines of 'PBW 343' pyramided with leaf rust resistance genes $L r 24$ and $L r 28$ was reported by Chhuneja et al., (2011).

For leaf rust infection, the coefficient of infection in $\mathrm{BC}_{2} \mathrm{~F}_{2}$ generation which was on par with resistant parent NIL PBW 343. This indicated the introgression of leaf rust resistance genes $L r 24$ and $L r 28$. Similar reports of improved leaf rust resistance through marker assisted introgression of $L r 24$ and $L r 28$ genes was reported by Revathi et al., (2010) and Chhuneja et al., (2005).

The present study highlighted the usefulness of DNA markers linked to resistance genes and revealed the importance of MAS in pyramiding the gene combinations of $L r 24$, Lr28 for leaf rust resistance in wheat. Since Lr24 is linked with stem rust resistance gene $S r 24$, the newly pyramided lines are expected to show additional resistance. The $\operatorname{Lr} 28$ gene remained effective for many decades in India and elsewhere, however, Bhardwaj et al., 2010 recently reported a new virulent pathotype 121 R60-1 from India, which appears closely related to the most prevalent pathotype 121R 63-1 (77-5).

Nevertheless, the lines obtained with different combination of rust resistance genes in DWR162 background are likely to provide enhanced durable resistance. These lines can be used for gene deployment after the testing of their yield potential at multi-locations.

The introgressed backcross segregants with high recovery of recurrent parent genome can be used in further studies to develop near isogenic lines of DWR162 with Lr24 and Lr28. 


\section{References}

Annapurnalilly, B., Balgounda, H., Mohinder, P., Subhash, B., Suryaprakash, R. and Shubhada, T., 2011, Validation and identification of molecular markers linked to the leaf rust resistance gene Lr28 in wheat. J. Appl. Genetics., 52:171-175.

Arati, Y., 2013, Pyramiding of leaf rust resistance genes, $L r 24$ and $L r 28$ into bread wheat variety, DWR162 (Triticum aestivum L.) through marker assisted selection. Ph. D. Thesis. Univ. Agri. Sci., Dharwad, Karnataka (India).

Bhardwaj, S. C., Parashar, M., Jain, S. K., Kumar, S., Sharma, Y. P., Sivasamy, M. and Kalappanavar, I. K. 2010, Virulence of Puccinia triticina on Lr28 and its evolutionary relation to prevalent pathotypes in India. Cereal Res. Commun., 38: 83-89.

Cherukuri, D. P., Gupta, P. K., Charpe, A., Koul, S., Prabhu, K. V., Singh, R. B. and Haq, Q. M. R., 2005, Molecular mapping of Aegilops speltoides derived leaf rust resistance gene $L r 28$ in wheat. Euphytica, 143: 19-26.

Chhuneja, P., Kaur, S., Vikal, Y., Bains, N. S. and Dhaliwal, H.S., 2005, Development of PBW 343 Near Isogenic Lines for Leaf Rust Resistance Genes Lr24 and Lr28. Crop Improve, 32(1): 1-7.

Chhuneja, P., Vikal, Y., Kaur, S., Singh, R., Juneja, S., Bains, N. S., Berry, O., Sharma, A., Gupta, S. K., Charpe, A., Prabhu, K. V. and Dhaliwal, H. S., 2011, Marker-assisted pyramiding of leaf rust resistance genes $L r 24$ and $L r 28$ in wheat (Triticum aestivum). Indian J. Agril. Sci., 81(3): 214-218.

Dadkhodaie, A., Karaoglou, H., Wellings, C. R. and Park, R. F., 2011, Mapping genes Lr53 and Yr35 on the short arm of chromosome $6 \mathrm{~B}$ of common wheat with microsatellite markers and studies of their association with Lr36. Theor. Appl. Genet., 122:479-487.

Dellaporta, S. L., Wood, J. and Hicks, J. B. 1983. A plant DNA mini-preparation: version II. Plant Mol. Biol. Rept., 1: 1921.

Dyck, P. L., and Samborski, D. J., 1982. The inheritance of resistance to Puccinia recondita in a group of common wheat cultivars. Can. J. Genet. Cytol, 24: 273283.

Gupta, S. K., Charpe, A., Koul, S. and Prabhu, K. V., 2006, Development and validation of SCAR markers cosegragating with an Agropyron elongatum derived leaf rust resistance gene Lr24 in wheat. Euphytica, 150: 233-240.

Kloppers, F. J., and Pretorius Z. A. 1997, Effects of combinations amongst $\operatorname{Lrl3}$, Lr34 and Lr37 on components of resistance in wheat to leaf rust. Plant Pathol, 46: 737-750.

Kolmer, J. A., Dyck, P. L. and Roelfs, A. P., 1991. An appraisal of stem and leaf rust resistance in North American hard red spring wheats and the probability of multiple mutations to virulence in populations of cereal rust fungi. Phytopathology, 81: 237-239.

Kumar, A. A., and Raghavaiah, P., 2004, Effect of the leaf rust resistance gene Lr28 on grain yield and bread-making quality of wheat. Plant Breed, 123: 3538.

McIntosh, R. A., Devos, K. M., Dubcovsky, J., Rogers, W. J., Morris, C. F., Appels, R., Somers, J. and Anderson, O. A., 2007, Catalogue of gene symbols for wheat: supplement: Supplement. Grain Genes.Website: http://wheat.pw.usda.gov.

Peterson, R. F., Campbell, A. B. and Hannah, A. E., 1948. A diagramatic scale for estimating rust severity on leaves and 
stems of cereals. Can. J. Res. Sect. C., 26: 496-500.

Prabhu, K. V., Gupta, S. K., Charpe, A. and Koul, S., 2004, SCAR marker tagged to the alien leaf rust resistance gene $\operatorname{Lr} 19$ uniquely marking the Agropyron elongatum gene Lr24 in wheat: a revision. Plant Breed. 123: 417-420.

Rao V. S., Misra S. C., Bhagwat M. D., Dixit R. N., Honrao B. K., Chavan A. M., Surve V. D., Khade V. M., Menon M. K., Brahma R. N., Sivasamy M. and Tomar S. M. S. 2007. Notification of crop varieties: A bread wheat variety MACS6145. Indian J. Genet., 67: 305.

Revathi, P. S., Tomar, M., Vinod, S. and Singh, N. K., 2010, Marker assisted gene pyramiding of leaf rust resistance genes Lr24, Lr28 along with stripe rust resistance gene $\mathrm{Yr} 15$ in wheat (Triticum aestivum L.). Indian J. Genet., 70 (40): 349-354.

Simons, K., Abate, Z., Chao, S., Zhang, W., Rouse, M., Jin, Y., Elias, E. and Dubcovsky, J., 2011, Genetic mapping of stem rust resistance gene $\mathrm{Sr} 13$ in tetraploid wheat (Triticum turgidum ssp. durum L.). Theor. Appl. Genet., 122: 649-658.

Singh, B., Tomar, S. M. S., Vinod and Singh, 2007, Notification of crop varieties: A bread wheat variety HD 2851. Indian J. Genet., 67: 305-306.

Tomar S. M. S., and Menon M. K. 2001. Genes for disease resistance in wheat. IARI, New Delhi, pp. 152.

\section{How to cite this article:}

Anil Kumar, G., R.R. Hanchinal, Shrinivas Desai and Suma Biradar. 2017. Marker Assisted Gene Pyramiding of Leaf Rust Resistance Genes Lr24 and Lr28 in the Background of Wheat Variety DWR 162 (Triticum aestivum L.). Int.J.Curr.Microbiol.App.Sci. 6(9): 1883-1893. doi: https://doi.org/10.20546/ijcmas.2017.609.232 